\title{
ПЕРВЫЕ ДАННЫЕ ПО МИНЕРАЛОГИИ И ГЕОХИМИИ ВЗВЕСИ ОНЕЖСКОГО ОЗЕРА.
}

Страховенко В. Д., Белкина Н. А., Ефременко Н. А., Потахин М. С., Субетто Д. А., Фролова Л. А., Нигаматзянова Г. Р., Лудикова А. В., Овдина Е. А.

\begin{abstract}
Аннотация
В настоящей работе приведены первые данные о минералогии взвеси, геохимии, количественном распределении, определенные с помощью седиментационных ловушек, установленных в Онежском озере (время экспозиции составляло 1 год - 2019 г.). Полученные данные о минералогогеохимическом составе современной взвеси водной толще Онежского озера сопоставлены с данными поверхностного слоя донных отложений озера (0-10 см). Впервые для Онежского озера получены данные о скоростях осадконакопления по веществу, определенные с помощью седиментационных ловушек. Полученные оценки о скоростях осадконакопления незначительно отличаются от результатов расчета скоростей осадконакопления методом радиоизотопоного датирования на основании распределения активности $210 \mathrm{~Pb}$ в верхнем слое донных отложений в совокупности с данными о 137Cs. Выявлено, что минеральная часть рассеянного осадочного вещества, поступившая в озеро, достигает донный осадок без существенных изменений. Геохимия вещества седиментационных ловушек во многом сходна с геохимией верхней части донных осадков (0-10 см) в различных районах Онежского озера. Рассеянный осадочный материал и донный осадок отличаются между собой количеством биогенной части (в слое донных осадков (010 см) биогенная часть теряет значительную часть органики), резким преобладанием в донных осадках железистой разновидности иллита и хлорита, в отличии от Mg-Fe разновидностей этих минералов во взвеси. Деградированные минералы слюд, привнесенными реками, регенерируются до нормальных железистых иллитов и хлоритов непосредственно в самой верхней части донного осадка. Донные отложения отличаются более высокими концентрациями марганца и молибдена, а материал из седиментационных ловушек - содержанием ртути.
\end{abstract}

\section{Ключевые слова:}

Онежское озеро, геохимия и минералогия, осадочный материал седиментационных ловушек, донные отложения, скорость осадконакопления 


\section{ПЕРВЫЕ ДАННЫЕ ПО МИНЕРАЛОГИИ И ГЕОХИМИИ ВЗВЕСИ ОНЕЖСКОГО ОЗЕРА.}

\section{В.Д. Страховенко ${ }^{1,2}$, Н.А. Белкина ${ }^{3}$, Н.А. Ефременко ${ }^{3}$, М.С. Потахин ${ }^{3}$, Д.А. Субетто ${ }^{4}$, Л.А. Фролова ${ }^{5}$, Г.Р. Нигаматзянова ${ }^{5}$, А.В. Лудикова ${ }^{6}$, Е.А. Овдина ${ }^{1}$}

${ }^{1}$ Институт геологии и минералогии им. В.С. Соболева СО РАН, г. Новосибирск, Россия, еmail:strahova@igm.nsc.ru

${ }^{2}$ Новосибирский государственный университет, г. Новосибирск, Россия

${ }^{3}$ Институт водных проблем Севера КарНЦ РАН,г. Петрозаводск, Россия; , e-таil: bel110863@mail.ru

${ }^{4}$ Российский государственный педагогический университет им. А. И. Герцена, г. СанктПетербург, Россия, e-mail:subetto@mail.ru

${ }^{5}$ Казанский федеральный университет, г. Казань, Россия, e-mail: larissa.frolova@kpfu.ru; gulnaraniga@mail.ru

${ }^{6}$ Институт озероведения Российской академии наук - обособленное структурное подразделение ФГБУН «Санкт-Петербургский Федеральный исследовательский центр Российской академии наук», г. Санкт-Петербург, Россия, e-mail: ellerbeckia@yandex.ru

\section{ВВЕДЕНИЕ}

Новые данные о глобальном переносе осадочного вещества, полученные за последние 50 лет, внесли существенные изменения в устоявшиеся представления о глобальных законах процессов континентальной седиментации [McCarthy, Degueldre, 1992; Buck, Bates, 1999; Шевченко, 2006; Лисицын и др., 2010 и др.]. Многие важные особенности образования, переноса осадочного вещества в рассеянной и растворенной его формах до настоящего времени почти не изучены [Лисицын и др., 2014]. Изучение донных отложений озёр, в которых записана и сохранена информация об изменениях климата, ландшафтов и экологических обстановок прошлого регионального и планетарного уровня с разрешением от столетий до года, позволяет реконструировать ход развития водоемов и их экосистем [Страхов, 1962; Субетто, 2009 и др.]. Изучение рассеянного осадочного вещества, его химического и минерального состава в сопоставлении с данными по донным отложениям актуально для получения информации об особенностях озерного осадконакопления, о геохимической роли биологических процессов в формировании аутигенных минералов и вкладе микрочастиц различного генезиса в формирование состава донных отложений континентальных водоемов.

В озере накапливается разнообразный материал: аллохтонная компонента с территории водосборного бассейна (твердая и растворенная фазы речного стока, эоловый 
материал, антропогенное вещество) и автохтонная компонента (материал, образованный в результате абразии берегов и дна водоемов, гидрохимических и гидробиологических процессов). Важно отметить, что при исследовании экосистемы очень большого озера (площадь зеркала >1000 км²), необходимо учитывать неравномерность развития крупно- и мелкомасштабных гидродинамических процессов, а также мозаичный характер антропогенного воздействия, проявляющийся не сразу, часто с длительным временным перерывом. Кроме того, в водной толще озера, добавляется биогенная составляющая взвеси: водоросли, макрофиты, детритный материал и вещество, вновь образованное в результате деятельности бактерий [Система ..., 2013]. Взвешенное вещество, поступающее в донный осадок, представляет собой сложную, полидисперсную, многокомпонентную систему из терригенного, биогенного и хемогенного материалов. Изучение закономерностей осадконакопления в водоемах предполагает использование седиментационных ловушек [Система ..., 2013].

Два крупнейших пресноводных природных водоема Европы - Ладожское и Онежское озера, содержат около $70 \%$ от общего запаса пресных вод в европейской части России. Вопросы сохранения Онежского озера объявлены одной из приоритетных задач Водной стратегии Российской Федерации (Постановление Совета Безопасности РФ, ноябрь 2014). Понимание современных процессов, происходящих в озерных экосистемах, и прогнозирование их изменений в будущем, невозможно без изучения закономерностей седиментогенеза с учетом совокупности всех геохимических факторов, минерального состава взвешенного вещества в водной толще и донных отложений с учетом их изменения во времени (послойное изучение кернов донных осадков) в сочетании с геоморфологией, особенностями ландшафтов водосборной территории и динамикой вод. Выявление специфики распределения природных содержаний химических элементов и радионуклидов в различных компонентах озерной экосистемы на разных уровнях её пространственной организации, является первым шагом к обнаружению ареалов с их аномальными концентрациями как естественной, так и техногенной природы.

Котловина Онежского озера расположена в северо-западной части Европейской России и находится в зоне соприкосновения двух крупных геологических структур Балтийского кристаллического щита и Русской плиты. Значительную часть котловины Онежского озера представляют раннедокембрийские образования Балтийского щита, сложенные на 80\% породами серии тоналит-трондьемит-гранодиорит (ТТГ) (серыми гнейсами). Южная часть котловины Онежского озера расположена среди вендпалеозойских пород платформенного чехла. К плитному комплексу относятся терригенные образования среднего и верхнего девона, каменноугольные-нижнепермские карбонатно- 
сульфатные породы, красноцветы верхней перми-триаса, маломощные континентальные морские отложения юры, мела и антропогена [Ранний..., 2005; Государственная ...., 2013; Арестова и др., 2015] . На многих участках водосборного бассейна Онежского озера кристаллические породы покрыты чехлом четвертичных отложений (межледниковые, континентальные и морские образования раннего, среднего и позднего плейстоцена [Атлас..., 2010; Онежская.., 2011]), которые интенсивно разрушаются под воздействием денудационных процессов в условиях гумидного климата. Формирование рельефа на прилегающих к озеру территориях связано с распространением четвертичных оледенений. Четвертичные отложения представлены ледниковыми, ледниково-озерными и флювиогляциальными осадками [Saarnisto, Saarinen, 2001]. Четвертичные ледниковые отложения и развитые на них почвы на водосборе Онежского озера, поставляют в озеро в виде взвеси много иллита (Mg-Fe состава), а также хлорит (Mg-Fе состава) [Онежская.., 2011]. Онежское озеро, по данным Н.А. Хотинского [1977], относится к ВосточноЕвропейской провинции Европейско-Сибирской подобласти темнохвойных лесов. Сосновые и еловые леса являются основной формацией. Их широкое развитие вокруг Онежского озера началось с субборельного периода [Лаврова, 2004]. Наличие на данной территории широколиственных пород является остатком растительного комплекса климатического оптимума голоцена. Начиная с субатлантического периода и по настоящее время в регионе наблюдается реконструировано развитие сосновых и еловых лесов с березой и ольхой [Филимонова, Лаврова, 2017].

Материал донных осадков Онежского озера, поступивший в воды озера в виде терригенного, органогенного, растворенного или взвешенного вещества, представлен в основном частицами алевритовой и пелитовой размерности [Семенович, 1973; Лозовик, Ефременко, 2017]. Эти частицы, поступившие в водную толщу озера и оседающие на дно, активно преобразуются в результате процессов механического разрушения, химического, биологического разложения и аутигенного минералообразования. Во время раннего диагенеза, в условиях открытой системы - реакции окисления органического вещества и восстановления соединений $\mathrm{N}, \mathrm{Mn}, \mathrm{Fe}, \mathrm{S}, \mathrm{C}$ и, как следствие, изменение значений Eh, $\mathrm{pH}$ и активности растворенного $\mathrm{CO}_{2}$, происходят растворение-переотложение и сорбция, которые сопровождаются, в том числе, ионным обменом между иловой и придонной водами и некоторым изменением химического состава формирующихся осадков [Субетто, 2009].

При изучении техногенной нагрузки на любую территорию, необходимо иметь в качестве точки отсчета реперные начальные величины, характеризующие «незагрязненную» площадь. В случае континентальной водной экосистемы, для прогноза 
её возможных изменений в условиях усиливающейся антропогенной нагрузки, необходима детальная информация о минералого-геохимическом составе донных отложений в прошлом. Именно данные о пространственно-временном изменении геохимического фона «экологически чистых осадков» помогают сформулировать критерии создания прогнозных моделей антропогенных трансформаций природных обстановок. Величинами геохимического фона для донных отложений Онежского озера могут быть концентрации микроэлементов в голоценовых озерных осадках из зон их контакта с позднеплейстоценовыми озерно-ледниковыми ленточными глинами.

Цель настоящей работы - (1) исследовать особенности распределения и химического состава осадочного вещества Онежского озера в его рассеянной форме, а затем и в концентрированной, т.е. в донных отложениях; (2) провести сравнительный анализ химического и минерального составов взвеси и верхних горизонтов донных отложений по всей акватории водоема для установления закономерностей современного осадконакопления в Онежском озере в связи с прогнозированием отклика его экосистемы на внешние воздействия в будущем. Эта тема исследования является актуальной, вследствие увеличивающейся эмиссии микрочастиц в атмосферу и в гидросферу нашей планеты.

\section{ОБЪЕКТЫ И МЕТОДЫ ИССЛЕДОВАНИЯ.}

Объект исследований - взвесь из воды и из седиментационных ловушек (СЛ), донные отложения, отобранные в различных частях акватории Онежского озера. Исследование взвешенного вещества, поступающего в воды Онежского озера разнообразным путем, потребовало установки СЛ более чем в двух десятках точек на его акватории. Для этого был сконструирован и изготовлен упрощенный вариант седиментационной ловушки УСЛ-100 (СЛ) в лаборатории палеолимнологии ИВПС КарНЦ РАН. Ловушка состоит из двух полиэтилентерефталатовых бутылок объемом 2 литра, диаметром 98 мм (рисунок 1). У бутылок удалены донные части. Бутылки скреплены между собой, образуя цилиндр с двойным конусом, нижний из которых выполняет роль пробосборника, а верхний препятствует потере собранного материала при подъеме и перемещениях ловушки. Подготовка и установка оборудования производилась в соответствии с принятыми правилами [Система ..., 2013]. Время экспозиции СЛ составляло 1 год. Так как интервал глубин в озере на участках, где была запланирована установка СЛ, варьировал от 30 до 100 м, то при постановке ловушек горизонтальный фал располагали не у дна, а в толще воды, что значительно упрощало его поиск и подъем при снятии приборов. Фал крепился к основному и вспомогательному буям, находящимся на 
глубине 7-10 м. Такая глубина определялась возможными скоростями течения, составляющими здесь в безледный период 1-3 см/с, тогда как ближе к поверхности воды эти величины могут достигать десятков см/с и приводить к заметному отклонению буйрепов от вертикали, тем самым снижая эффективность работы ловушки [Онежское...., 2010]. Результаты использования приведенных выше способов постановки, поиска и снятия ловушек следует считать вполне удовлетворительными. После годовой экспозиции при приемлемых погодных условиях было поднято 17 из 20 станций, в трех случаях поиск ловушек пришлось отложить из-за погодных условий.

Водные образцы, пробы взвешенного материала из СЛ и воды, пробы донных осадков в отдельных точках отобраны в сентябре 2019 года по всей акватории Онежского озера: 1) Большое Онего, скв. B1; 2) Малое Онего скв. L11, N1; 3) Центральное Онего, скв. C4; 4) Южное Онего скв. S3; 5) Уницкая губа, скв. GU-4; 6) Лижемская губа скв. Gl.; 7) Кондопожская губа, скв. К6; 8) Петрозаводская губа, скв. Р3; 9) Повенецкий залив скв. W2. Места пробоотбора вынесены на карту (рисунок 2).

На основе вертикального распределения мутности (измерения “in situ” мультипараметрическим зондом STD) осуществляется отбор проб воды (батометр Рутнера). Затем проводилось ее разделение на твердую, коллоидную и растворенную части методом последовательного фильтрования (0,8 и 0,45 мкм). Весь объем воды в батометре (высота 1 м) последовательно делился по вертикали на 7 водных образцов объемом по 1 л. Взвесь выделяли “in situ” методом вакуумной фильтрации с использованием специально подготовленных заранее взвешенных мембранных фильтров с диаметром пор 0.45 мкм. Фильтры со взвесью помещались в чашки Петри. Фильтраты воды консервировались концентрированной азотной кислотой из расчета 1 мл кислоты на 100 мл пробы для последующего определения в них металлов и микроэлементов.

Донные отложения отбирались послойно с шагом 1 см специальными пробоотборниками (Limnos, Алексона), позволяющими сохранить границу вода-дно ненарушенной. Осадочное вещество из ловушек выделялось общепринятым методом прямой вакуумной мембранной ультрафильтрации с использованием ядерных фильтров с диаметром пор 0,45 мкм. Проанализировано 11 проб осадочного вещества из седиментационных ловушек, 31 фильтр и 52 пробы верхнего окисленного слоя донных отложений (от 2 до 35 см), 27 проб гомогенного алевро-пелитового слоя донных отложений (от 5 до 100 см). Работы проведены с борта НИС «Эколог». После поднятия воды и керна донных отложений на борт корабля, визуального осмотра проводилось определение проводилось определение t, pH, Eh, $\mathrm{CO}_{2}, \mathrm{O}_{2}$ воды, донного осадка и литологического описания колонок. 
Керн донных отложений изучался послойно с шагом 1-2 см комплексом геохимических и петрографо-минералогических методов, вклющающих рентгенфлуоресцентный анализ (РФА), атомно-абсорбционный анализ (АА), анализ с использованием ICP MS. Минеральный состав отложений установлен методами рентгеновской дифрактометрии (XRD) и инфракрасной (ИК) спектроскопии. Детальное изучение текстурно-структурных особенностей осадка, морфологических особенностей минералов, химического состава и структурных данных на уровне отдельных зерен, сростков и пседоморфоз проведено с использованием сканирующего электронного микроскопа (СЭM) MIRA 3 TESCAN. Аналитические работы выполнены в Аналитическом центре многоэлементных и изотопных исследований СО РАН (ЦКП МИИ СО РАН, г. Новосибирск).

Химические анализы (минерализация и ионный состав воды $\left(\mathrm{Ca}^{2+}, \mathrm{Mg}^{2+}, \mathrm{Na}^{+}, \mathrm{K}^{+}\right.$, $\mathrm{HCO}_{3}{ }^{-}, \mathrm{SO}_{4}{ }^{2-}, \mathrm{Cl}^{-}$), органическое вещество (цветность, ПО, ХПК, БПК), биогенные элементы ( $\mathrm{P}_{\text {мин, }} \mathrm{P}_{\text {общ, }} \mathrm{NH}_{4}{ }^{+}, \mathrm{NO}_{3}{ }^{-}, \mathrm{NO}_{2}^{-}, \mathrm{N}_{\text {орг }}$ ), литофильные элементы (Fe, $\mathrm{Si}, \mathrm{Al}, \mathrm{Mn}$ ), растворенные газы $\left(\mathrm{CO}_{2}, \mathrm{O}_{2}\right)$ и $\mathrm{pH}$, а также физические и химические характеристики донных отложений (потери при прокаливании $550^{\circ} \mathrm{C}$, зольность, $\mathrm{C}_{\text {орг }}$, растительные пигменты, гуминовые и фульвовые кислоты, $\mathrm{N}_{-} \mathrm{NH}_{4}{ }^{+} \mathrm{N}_{\text {орг. }} \mathrm{P}_{\text {лаб., }} \mathrm{P}_{\text {общ., }} \mathrm{Fe}, \mathrm{Mn}, \mathrm{Eh}$ и pH)) выполнены в лабораториях гидрохимии и гидрогеологии и палеолимнологии ИВПС КарНЦ РАН (г. Петрозаводск).

Для проведения анализа осаждающейся в Онежском озере пыльцы отобраны 23 образца поверхностных донных отложений (из всех районов акватории Онежского озера, верхний 10-см слой) и 4 образца твердой взвеси из седиментационных ловушек из Южного, Малого Онега, Кондопожской и Петрозаводской губ. Подготовка проб к палинологическому анализу проведена по методике Фаегри-Иверсена, но без этапа ацетолиза [Faegri, Iversen, 1989]. Идентификация пыльцы и спор осуществлялась с использованием отечественных и зарубежных определителей и атласов [Куприянова и Алешина, 1972, 1978; Reille, 1992, 1995, 1998]. Микроскопирование образцов проводилось с помощью светового микроскопа Axio Imager A2 (Carl Zeiss, Германия) при увеличении в 400 раз. С целью определения концентрации пыльцы к образцам добавлялись маркеры Lycopodium tabl. [Stokmarr, 1972]. Подсчет пыльцевых зерен в спорово-пыльцевых спектрах (далее СПС) проводился минимум 300 единиц. Процентное содержание каждого таксона рассчитано от общей суммы пыльцы и спор. Для построения спорово-пыльцевой диаграммы использовался пакет программ Tilia/Tilia-Graph, разделение на локальные зоны в диаграммах осуществлено программой CONISS [Grimm, 2004]. 
Пробы для диатомового анализа были высушены при комнатной температуре для последующего расчета концентраций. Пробоподготовка выполнена по стандартной методике с применением $\mathrm{H}_{2} \mathrm{O}_{2}$ для окисления органического вещества [Давыдова, 1985]. Для идентификации видов использовались определители [Krammer, Lange-Bertalot, 19861991]. Концентрации створок диатомей в 1 г сухого осадка рассчитывались по формуле, предложенной Н.Н. Давыдовой [1985].

\section{РЕЗУЛЬТАТЫ ИССЛЕДОВАНИЯ}

\section{Гидрогеохимия вод, геохимический и минеральный составы донных отложений}

Согласно лимнологическому районированию территория Карелии относится к подобласти железо-кремнеземо-гумусового накопления, где поверхностные воды насыщены органическим веществом кислотной природы, количество которого сопоставимо по содержанию с минеральными компонентами [Холодов и др., 2012; Лозовик и др., 2017, 2020]. Воды существенно обогащены Fe и Si. Железо поступает в озеро как во взвешенной, так и в растворенной форме в виде комплексных соединений трехвалентного железа с гумусовыми веществами, а также металлоорганических комплексов железа двухвалетного которые легко ассоциируется с гуминовыми и фульвокислотами [Россолимо, 1964; Бискэ и др., 1971; Лозовик и др., 2017, 2020; Холодов и др., 2012; Белкина 2005, 2006, 2014, Кулик и др. 2020 и др.]. Кремний в виде коллоидов $\mathrm{SiO}_{2}$. Взвешенные формы железа представлены преимущественно аморфными и кристаллическими гидрооксидами железа и его силикатами (иллит, хлорит) [Гордеев, 1983; Лозовик, 2006]. Обобщив большой материал В.В. Гордеев по рекам мира, а П.А. Лозовик по рекам и озерам Карелии, пришли к выводу, что, растворенное железо, образует сложные комплексные соединения с фульво_ и гуминовыми кислотами, причем металлоорганические соединения составляют 80-100\% форм железа в растворе. Железо, образуя простые и комплексные ионы с положительным или отрицательным зарядом, формирует типичные коллоидные формы. Их возникновение на территории Карелии связано с высоким содержанием в породах железа в сочетании с подзолообразовательными почвенными процессами. Среди почв водосборного бассейна Онежского озера наиболее распространены подзолы, что обеспечивает высокую миграционную способность железа [Онежское озеро, 2010].

Наиболее полно процессы формирования донных отложений в Онежском озере рассмотрены в работах [Семенович, 1973; Васильева и др. 1990, Белкина 2007, 2010, Strakhovenko et.al., 2020a, b]. В работе Н.И. Семеновича [1973] детально охарактеризован гранулометрический состав донных отложений, построены карты и диаграммы 
пространственного распределения различных гранулометрических фракций в донных отложениях по акватории озера и глубине. Показано, что Онежское озеро относится к водоемам с накоплением железа в донных отложениях. Согласно данным, опубликованным П.М. Лозовиком [2017] ежегодно в Онежское озеро поступает 80-90 тыс. т взвешенных веществ, что не превышает $10 \%$ от суммарного количества вещества, приносимого в водоем, главным образом, реками. Минеральная часть обломочного материала в основном состоит из кварца и полевых шпатов. Поступление большого количества растворенного аллохтонного органического вещества гумусовой природы (>285000 т С С в год) способствует развитию деструкционных процессов в озере. Преимущественное развития подзолов иллювиально-железистого и иллювиальногумусового-железистого типа горных породах водосборного бассейна обеспечивает значительное поступления в озеро растворенного кремния (около 30000 т в год), что вместе с большой продолжительностью светового дня (до 20 часов, май-август) способствует развитию диатомового комплекса фитопланктона. Соотношение поступающих в озеро биогенных элементов ( $\mathrm{N}: \mathrm{P}>10)$ определяет лимитирование экосистемных процессов по фосфору [Белкина, 2016].

Геохимический и минеральный составы донных отложений Онежского озера, приведены в статьях Страховенко В.Д. с соавторами [Strakhovenko et.al., 2020a, b]. В данных работах показано, что верхнеголоценовые донные отложения Онежского озера в целом наследуют состав терригенного материала, поступающего в водоем с речным стоком. Установлено, что среди аутигенных минералов преобладают опал панцирей диатомей, Fe-иллит и Fe-хлорит, являющиеся основными концентраторами железа в донных илах. В условиях гумидного климата северных широт и высоких концентраций железа и кремния в водах озера, происходит преобразование нестабильных компонентов детритовых иллитов и хлоритов в железистые разновидности. Присутствие значительных количеств мусковита в донные отложения Онежского озера связано с размывом более древних ледниковых отложений и шунгитовых пород, в которых преобладает серицит. Наличие железомарганцевых микроконкреций в донных отложениях Онежского озера и их локализация на дне определяется расположением водоема в северной гумидной зоне, в железо-марганцевой геохимической провинции, а также наличием окислительновосстановительного геохимического барьера в донных отложениях на определенной глубине от границы раздела сред «вода-донный осадок». Установлено присутствие двух типов разрезов верхнеголоценовых донных отложений [Strakhovenko et.al., 2020a]. При высоком содержании в надиловых водах кислорода на определенной глубине от границы раздела фаз вода-донный осадок происходит формирование рудных слойков. В строении 
рудного слойка выделяется тонкий прослой из марганцевых микроконкреций (бёрнессит, пиролюзит), ниже которого в слое резко преобладает гётит различной морфологии и степени кристалличности (от микроконкреций до тонкоигольчатых, листоватых кристаллов и псевдоморфоз по органическим остаткам). При низких концентрациях кислорода рудные слои в донных отложениях отсутствуют и ниже наилка сразу залегают неслоистые серо-зеленые гомогенные илы, аналогичные тем, что присутствуют в нижних частях разрезов первого типа колонок.

Химический состав воды Онежского озера соответствует гидрокарбонатному классу группы кальция: $\frac{\mathrm{HCO}_{3}^{-} 710 \mathrm{SO}_{4}^{2-} 180 \mathrm{Cl}^{-} 11}{\mathrm{Ca}^{2+} 490 \mathrm{Mg} \mathrm{Mg}^{2+} 32 \mathrm{Na}^{+} 16000 \mathrm{~K}^{+} 3} \quad$. По акватории озера состав надиловых (20 см над донным осадком) вод в основном слабо отличается от состава основной водной массы, что связано с хорошей циркуляцией вод озера. В надиловой воде фиксируется лишь незначительное увеличение содержаний углекислого газа, органического азота, фосфора, марганца, железа, кремния. Контрастно проявляются отличия в содержаниях $\mathrm{O}_{2}$, Mn, Fe в надиловых водах в отдельных точках пробоотбора, например, в Петрозаводской и Уницкой [Белкина и др., 2016].

\section{Минеральный и геохимический состав осадочного материала, определенные с помощью седиментационных ловушек}

Тонкодисперсная взвесь, выделенная из Онежской воды в разных районах озера, в местах установки СЛ, изучена методом атомной абсорбции и с помощью сканирующего электронного микроскопа. К сожалению, количество вещества на фильтрах, выделенного из онежской воды, оказалось на данном этапе недостаточным, чтобы провести весь спектр аналитических работ.

Электронно-микроскопическое исследование образцов взвеси на фильтрах показало низкие концентрации минеральной составляющей, что в общем характерно для пресных озер северных территорий [Система ..., 2013]. Нами выявлены близкие спектры минералов взвеси в открытых водах озера. Установлено, что материал взвеси приблизительно одинаков в разных частях озера и представлен биогенной рентгеноаморфной массой (панцири и биодетрит диатомовых водорослей, пыльца и споры) с отдельными зернами обломочных минералов, минеральными агрегатами, чешуйчатыми образованиями слоистых силикатов и сгустками окислов, гидроокислов марганца и железа (рисунок За). Важно отметить, что встречаются крупные отдельные зерна минералов (более 20-50 мкм), но в основном это агрегаты изометричной формы, состоящие из слепленных мелких зерен минералов (пелитовой размерности) и частиц биодендрита (мелкие обломки диатомей, шарообразные частицы (пыльцы, спор)) - 
пеллетные комки. Во взвеси на фильтрах диагностирован широкий спектр минералов: кварц, гидроокислы железа (резко преобладают), плагиоклаз (альбит, олигоклаз, андезин), калиевые полевые шпаты, мусковит, иллит (Mg, Fe), хлорит (Mg, Fe). В количествах меньше 5\% присутствуют амфибол (тремолит-актинолит, роговая обманка), пироксен (диопсид-геденбергит), эпидот и каолинит. Во всех пробах встречены отдельные зерна или кристаллы акцессорных минералов: магнетит, ильменит, рутил, титанит, апатит и монацит. В минеральном веществе, собранном на фильтры в Южном Онего и Уницкой, Лижемской губах, количество мусковита значительно возрастает относительно других минералов (рисунок 3б). Кроме того, во взвеси Кондопожской и Петрозаводской губ, Центрального и Малого Онего в значительных количествах определены крупные и мелкие агрегаты окислов марганца (рис. Зв). Минеральный состав взвеси слабо зависит от глубины и отличается от места отбора проб абсолютным содержанием взвеси на фильтре и соотношением в ней количества мусковита, размерностью и составом акцессорных минералов, а также наличием или отсутствием Мn-минералов. В Кондопожской губе установлено значительное количество оолитов (шаровидные стяжения, имеющие состав либо шамозита, либо сложного соединения, наиболее близко пересчитывающегося на (Mg, $\mathrm{Fe}, \mathrm{Na})$ иллит. Шамозит может иметь самое различное происхождение, так как может формироваться в водной среде в условиях дефицита кислорода, а также в дерновоподзолистых почвах, развитых на продуктах изменения основных пород.

Определение содержаний макро- и микроэлементов во взвеси на фильтрах проводилось методом АА. Содержание $\mathrm{Si}$ (валового) во взвеси вод Онежского озера напрямую измерить не удалось. Аншлифы проб взвеси изучались методом оптической микроскопии на микроскопе Olympus BX50. Проба просматривается под микроскопом для диагностики всех фаз и визуальной оценки их содержаний. Затем проводится пересчет содержаний на пробу (в процентах) методом подсчета зерен. Изучение показало, что содержание Si слабо колеблется и находится в пределах 30-35 \% от концентрации взвеси. Высокие его содержания связаны, как уже было описано выше, с присутствием как

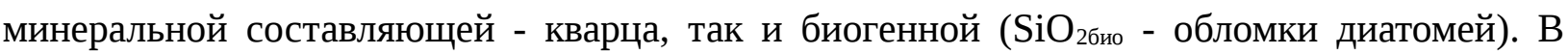
таких же количествах присутствует железо (около 35\%), минимальное содержание Fе обнаружено в Уницкой губе, где оно составляло около 25\% от концентрации взвеси. В распределении $\mathrm{Al}$ прослеживается увеличение его содержаний до 15-18\% в северной части озера (Повенецкая губа, Малое и Большое Онего) при общем содержании в других районах озера около 10\%. Содержание Mg слабо колеблется и находится в пределах 6-8\% от концентрации взвеси. Высокие значения Mn (около 6\%) характерны для Кондопожской и Петрозаводской губ, при общем содержании $\mathrm{Mn}$ в других районах озера около 3\%. 
Наиболее контрастно по акватории озера распределен Са во взвеси. Его значения варьируют от 1 до 23\%, составляя в среднем 4\%. Наибольшие содержания Са выявлены в Центральном Онего и Уницкой губе. Среднее содержание К во взвеси по всему озеру составляет около 6\% от общей концентрации взвеси. Повышенное содержание К (10\%) характерно для Лижемской, Уницкой губ и Южного Онего. Эти геохимические данные хорошо коррелируют с минеральным составом взвеси. Так, повышенные количества K связаны с увеличением содержания мусковита. Контрастное распределение Са во взвеси по акватории озера определяется либо присутствием зерен доломита (Центральное Онего), либо появлением основного плагиоклаза - битовнита (Уницкая губа). Именно во взвеси на фильтрах Кондопожской и Петрозаводской губ, где выявлены высокие концентрации марганца, присутствуют в большом количестве сгустки и изометричные агрегаты, сложенные оксидами марганца.

Осадочный материал СЛ, установленных в аккумуляционных зонах в разных районах озера, представлен в верхней части неконсолидированной взвесью охристого или буро-красного цветов мощностью от 1 до 3 см и плотностью близкой к плотности воды, ниже залегает коллоидный желеобразный ил охристого цвета пелитовой размерности коричневого цвета до 5 см и далее уплотненный осадок до 20-25 см, иногда зелено-серого цвета. По своим физико-химическим характеристикам осадочный материал из СЛ представляет собой коллоидную систему со средней плотностью 1,06 г/мл (от 1,01 до 1,09 г/мл), имеющую окисленный характер (Еһ изменяется от 270 до 376 мВ) и нейтральные значения $\mathrm{pH}$ (от 6,3 до 7,3) (таблица 1). Осадочный материал, поступающее на дно в Кондопожской губе, содержит аммонийного азота и минерального фосфора в 2 раза больше, чем во взвесях других районов озера. Восстановительные условия формирования в Кондопожской губе донного осадка подтверждаются наличием фрамбоэдров пирита, присутствующих только в этой части озера.

Детальное изучение текстурно-структурных особенностей осадочного материала из СЛ, морфологических особенностей минералов, химического состава и структурных данных на уровне отдельных зерен, сростков под микроскопом (оптический микроскоп Olympus BX50, увеличение 20-60 раз) и с использованием CЭМ (MIRA 3 TESCAN) показало, что его валовый минеральный состав из разных районов Онежского озера достаточно однообразен. На фоне тонкодисперсного материала (кварц, полевые шпаты, иллит, мусковит, хлорит, гидроокислы железа, биогенный детрит) пелитовой размерности выделяются крупные панцири диатомовых водорослей, а также крупные угловатые зерна, отдельные кристаллы тех же минералов, а также темноцветных и акцессорных минералов, таких как актинолит, роговая обманка, диопсид, эпидот, титанит, магнетит, ильменит, 
циркон, рутил, апатит, монацит и др. (рисунок 4). В веществе из СЛ Кондопожской губы установлено значительное количество агрегатов шаровидной морфологии полых внутри (рисунок 5а) с пористой текстурой и имеющих состав калиевого полевого шпата, шаровидных агрегатов (оолитовые стяжения, имеющие состав Fe-хлорита (рисунок 5б), и шаровидные агрегаты кварца с включениями скелетных кристаллов Fе-хлорита (рисунок 5в). Скорее всего это агрегаты техногенного происхождения - окатыши, используемые в технологическом процессе очистки вод Кондопожского бумажного комбината или летучий пепел от ТЭЦ ОАО «Кондопога».

Важно отметить, что в осадочном материале СЛ доминируют угловатые зерна кварца, альбита и агрегаты чешуйчатой, спутанно-волокнистой микроструктуры иллита $(\mathrm{K}, \mathrm{Ca})_{<1}(\mathrm{Fe}, \mathrm{Mg})(\mathrm{Fe}, \mathrm{Al})_{3}\left[\mathrm{Si}_{4} \mathrm{O}_{10}\right](\mathrm{OH})_{4}$, которые во взвеси на фильтрах присутствуют в резко подчиненном количестве (рисунок 6). Количество скелетов диатомей наоборот в осадочном материале СЛ уменьшается относительно других компонентов.

Исследования геохимического состава материала из СЛ в сравнении с составом взвеси фильтров и донных отложений в каждой отдельной станции опробования показало, что состав осадочного материала СЛ более однообразный (усредненный). Нормирование средних содержаний элементов в пробах, отобранных на различных участках акватории Онежского озера на их содержание в PAAS (постархейский средний австралийский глинистый сланец) [Тейлор, МакЛеннан, 1988]), позволило установить, что содержание макроэлементов в осадочном материале СЛ из разных районов озера отличаются незначительно, за исключением Na и Mn (рисунок 7). При этом вариации концентраций $\mathrm{Mn}$ в донных отложениях и во взвеси фильтров значительно выше. Состав взвеси фильтров отличается разбросом абсолютных значений практически по всем элементам и разбивается на три группы: Южное Онего; Уницкая, Лижемская, Кондопожская губы и вся остальная часть акватории.

Впервые, проведено сопряженное изучение состава и тренда распределения макрои микроэлементов материала из СЛ и донных отложений в каждой отдельной станции опробования из разных районов озера (рисунок 8). Сравнение данных по средневзвешенным значениям содержаний изученных элементов в донных отложениях и материале СЛ Онежского озера с усредненными концентрациями элементов в горных породах водосборной площади (гранито-гнейсы и TTG Балтийского щита, вулканогенноосадочные породы основного ряда, шунгитовые породы, осадочные породы Русской плиты), взятые из литературных источников [Онежская..., 2011; Ромашкин и др., 2014, Ронов, Мигдисов, 1996], показало, что они значительно отличаются как в большую, так и в меньшую сторону. Можно предположить унаследованность содержаний всех изученных 
микроэлементов в донных осадках от пород водосборных площадей, если усреднить их величины, кроме Mn и Hg. Согласно проведенным исследованиям, в донных отложениях наблюдаются более высокие концентрации $\mathrm{Mn}$, особенно в Петрозаводской, Кондопожской и Лижемской губах. Высокие концентрации Нg выявлены в материале СЛ Лижемской губы, Повенецкого залива, Большого и Малого Онего.

\section{Скорости осадконакопления}

Впервые для разных районов Онежского озера оценены скорости осадконакопления по массам вещества, накопленного в СЛ. Скорость осадконакопления в зависимости от района изменяется более чем на порядок: от 1 мм до 3 см свежеосажденного неконсолидированного вещества или от 0,1 до 2,8 мм/год уплотненного грунта (расчет на глубину 20 см). Самые высокие скорости осадконакопления, установлены в Кондопожской губе (от 0,6 до 2,8 мм в год). Это связано с влиянием сточных вод Кондопожского ЦБК, содержащих большое количество взвешенного вещества. Скорости осадконакопления в открытых районах озера, полученные на основе натурных наблюдений, сопоставлены со скоростями осадконакопления полученными на основе датирования возраста донных отложений путем оценки распределения в разрезах керна активностей ${ }^{137} \mathrm{Cs}$ и ${ }^{210} \mathrm{~Pb}$ [Strakhovenko et al, 2020a]. Они слабо отличаются от уплотненного осадка СЛ, так, для Малого Онего (0,23 мм/год и 0,16 мм/год соответственно) и для Южного Онего (0,43 мм/год и 0,47 мм/год соответственно) (таблица 2). Однако, для неконсолидированной самой верхней части донного осадка (0-2 см) и для неконсолидированной взвеси из СЛ для Южного Онего скорости осадконакопления отличаются на порядок (1,48 мм/год и 11,66 мм/год соответственно). Следовательно, сопоставление таких данных нужно продолжить.

\section{Диатомовый анализ}

Впервые изучен состав диатомовых комплексов из седиментационных ловушек в Онежском озере. Ловушки были установлены на глубине 1 м от поверхности дна и экспонировались в течение 1 года (сентябрь 2018 - сентябрь 2019). Результаты диатомового анализа позволяют охарактеризовать состав диатомовой флоры за указанный период, выявить сходство и различие между станциями, расположенными в Петрозаводской, Кондопожской, Уницкой и Лижемской губах, заливах Большое и Малое Онего, Заонежском и Повенецком заливах, а также в южной части Онежского озера.

Все пробы характеризуются высокими концентрациями створок диатомей (77-167 млн), максимальное содержание створок в 1 г сухого осадка отмечено в пробе из Лижемской губы (255 млн). Планктонные диатомеи преобладают на всех 12 станциях (6192\%). Наиболее широко распространенные и многочисленные виды в составе диатомовых комплексов - Aulacoseira islandica (16-45\%) и A. subarctica (13-42\%). A. islandica, 
нейтрофил, обитающий в широком диапазоне трофических условий, доминирует в весеннем фитопланктоне крупных глубоководных озер - Ладожского и Онежского [Растительные ..., 1968; Вислянская, 1999; Чекрыжева, 2015], в отдельных частях озера преобладает также в осеннем фитопланктоне [Растительные ..., 1968]. Aulacoseira subarctica (вследствие своей морфологической изменчивости ранее определявшаяся в Ладожском и Онежском озерах как Aulacoseira distans var alpigena (A. alpigena), A. italica, или A. italica ssp subarctica) является со-доминантом A. islandica в весеннем фитопланктоне [Растительные ..., 1968; Чекрыжева, 2015]. Она предпочитает олигомезотрофные условия. Резкое увеличение ее численности отмечалось в Кондопожской губе в результате антропогенного эвтрофирования [Онежское озеро. Экологические.., 1999]. Однако в пробах из седиментационных ловушек наиболее высокое содержание этого вида характерно для Петрозаводской губы, залива Большое Онего и Лижемской губы. В свою очередь, в пробах из Кондопожской губы многочисленнен род Aulacoseira, достигающий численности доминанта - алкалифильная, эвтрофная Ambigua (24-32\%), что очевидно является следствием более высокой фосфорной нагрузки в этом заливе.

\section{Палинология}

29 палиноморф, представленные 13 древесными и травянистыми и 3 споровыми таксонами, идентифицировано в результате палинологических исследований образцов поверхностных донных осадков и материала СЛ Онежского озера. 88-98\% от общей суммы пыльцы и спор составляет древесная пыльца. В отложениях доминирует пыльца сосны Pinus sylvestris (30-80\%), субдоминантом выступает пыльца березы Betula spp. (544\%) и ели Picea sp. (5-30\%). Содержание пыльцы Alnus также высоко и составляет 1-15\%. В незначительном количестве в отложениях присутствует пыльца ивы Salix, тополя Populus, клена Acer, лещины Corylus, вяза Ulmus, липы Tilia. Из хвойных пород кроме пыльцы сосны и ели отмечена пыльца пихты Abies, лиственницы Larix и хвойника Ephedra. Пыльца травянистых растений занимает в СПС подчиненное положение и составляет от 2 до 12\%. Среди них преобладает пыльца осоковых Сурегасеае, амарантовых Amaranthaceae и злаковых Роасеае. В меньшем количестве представлена пыльца рода Рубус Rubus семейства розоцветных Rosaceae, полыни Artemisia, рдестовых Potamogetonaceae, мареновых Rubiaceae, бобовых Fabaceae, гвоздичных Caryophyllaceae, капустных Brassicaceae, зонтичных Аріасеае, вересковых Ericaceae. Споровые растения в спектрах представлены спорами Sphagnum (его содержание варьирует в пределах 3-11\%), папоротниковидными Polypodiophyta и бриевыми мхами Bryales.

На рисунке 9 изображена палинодиаграмма, поделённая на 8 палинологических зон, соответствующих различным участкам озера, в которых проводился отбор образцов 
(рисунок 9). В СПС образцов донных отложений Большого Онеги обнаружены максимальные проценты содержания пыльцы P. sylvestris (80\%), Picea (30\%), Alnus (15\%). Максимально высокое содержание пыльцы Betula spp. (50\%) отмечено в СПС образцов СЛ Кондопожской губы, пыльцы Ulmus - в СПС образцов донных отложений Повенецкого залива.

\section{ОБСУЖДЕНИЕ}

Сравнение геохимического, минерального и биогенного составов материала из СЛ и донных отложений из разных частей Онежского озера показал, что их составы практически полностью идентичны, с небольшим преобладанием биогенной части в осадочном материале СЛ.

Подавляющая часть донного осадка и материала из СЛ Онежского озера представлена частицами пелитовой, алевропелитовой размерности и состоит из кварца, полевых шпатов, мусковита, иллита, хлорита и минеральных фаз железа (гетита, фосфата железа), а также скелетов, обломков панцирей диатомей. Максимальное количество скелетов диатомей отмечается во взвеси на фильтрах, уменьшаясь в материале СЛ и особенно в донных осадках. Важно отметить, что во взвеси на фильтрах чешуйчатые, спутанно-волокнистые микроструктуры иллита и крупные выделения хлорита имеют в составе магния больше, чем железа и присутствуют в резко подчиненном количестве, относительно массы других основных минералов. В осадочном материале СЛ доминируют агрегаты чешуйчатой, спутанно-волокнистой микроструктуры иллита $(\mathrm{K}, \mathrm{Ca})_{<1}(\mathrm{Fe}, \mathrm{Mg})$ $(\mathrm{Fe}, \mathrm{Al})_{3}\left[\mathrm{Si}_{4} \mathrm{O}_{10}\right](\mathrm{OH})_{4}$, в составе которого железо либо равно магнию, либо преобладает незначительно. В донных осадках уже резко преобладает железистый иллит. Что касается состава хлорита, то в основном в составе хлорита во взвеси на фильтрах и взвешенном веществе СЛ количество магния и железа примерно одинаково. Кроме того, в составе материала СЛ в Кондопожской губе и Большого Онего выявлены шаровидные агрегаты, имеющие состав Fе-хлорита и шаровидные агрегаты кварца с включениями скелетных кристаллов Fе-хлорита, имеющие пористую текстуру, и скорее всего, техногенное происхождения (шлак). В научных работах, исследующих минеральный состав тонкодисперсных фракций почвообразующих пород и почв показано, что в условиях сурового климата преобладает механическая дезинтеграция минералов и в результате этого тонкая илистая составляющая почв в основном состоит из мельчайших обломков кварца и полевого шпата и незначительных количеств биотита, иллит-смектита, так как основная масса смектитовых фаз четвертичных отложений полностью разрушается с образованием рентгеноаморфного материала [Чижикова и др., 2000; Федорец, 2009; 
Лисицын, 2014 и др.]. При этом, исходя из состава и морфологии выделений иллита, хлоритов взвеси на фильтрах (в них количество железа и магния примерно одинаково, сильно изогнутые, чешуйчатые, расщепленные пластинки) в условиях сурового северного, гумидного климата они выносятся реками в деградированном состоянии, и не изменяются в процессе переноса. Переработке данные минеральные фазы подвергаются уже в конечном водоеме осаждения. Таким образом, Fе-иллит, Fе-хлорит могут быть результатом переформирования осадочного вещества минеральной природы в ходе различных процессов непосредственно в озере, возможно с участием живого вещества. Железо, которое высвобождается в озерной воде в результате уменьшения концентраций гумусовых кислот (во взвеси на фильтрах присутствуют стяжения, сложенные гидроокислами железа), может также адсорбироваться деградированными минералами слюд, привнесенными реками, которые регенерируются до нормальных железистых иллитов и хлоритов непосредственно в самой верхней части донного осадка (наилке). Следовательно, данные минералы формируются в процессе седиментогенеза и имеют аутигенное происхождение. Относительно малое содержание фосфора в горных породах и почвах влечет за собой его низкие концентрации в поверхностных водах и как следствие, лимитирование озерной экосистемы по фосфору. Взвешенный материал СЛ обычно больше содержит органического детрита, чем донные осадки, что определяет небольшое превышение абсолютных содержаний элементов в донных осадках. Отсутствие изоморфной примеси марганца в составе минералов современной терригенной фракции не позволяет на данный момент определить его источник, так как и в абсолютных количествах Mn больше в донных осадках, чем в горных породах водосборных территорий. Этот вопрос требует дальнейших исследований.

Для образцов донных отложений Южного и Малого Онеги, Петрозаводской, Лижемской, Уницкой губ и Повенецкого залива характерно снижение общей концентрации пыльцы и спор с увеличением глубины отбора материала (от 65 до 10 зерен/г), что объясняется разрушением некоторой части пыльцы и спор под воздействием различных факторов окружающей среды. Однако в образцах Большого и Центрального Онего наблюдается обратная ситуация, когда с глубиной отбора увеличивается общая концентрация пыльцы и спор, что может быть следствием вымывания пыльцы и спор из верхних слоев осадка в нижние.

Максимально высокая концентрация пыльцы и спор зафиксирована в поверхностных донных отложениях Кондопожской губы (до 150 зерен/г), расположенной на северо-западе озера. Именно на побережье Кондопожской губы располагается техногенный объект - целлюлознобумажный комбинат, который поставляет в озеро много 
органического материала со сточными водами. Так, согласно работе Куликовой Т.П. и Сярки М.Т. [2004] в этом районе озера наблюдается уникальная ситуация: показатели развития популяции ветвистоусого рачка Daphnia cristata Sars в некоторые годы достигают экстремально высоких для Онежского озера значений. Кроме того, в Кондопожскую губу сливают городские сточные воды Петрозаводска и Кондопоги [Калинкина и др., 2017]. Возможно, этими факторами объясняется поступление в озеро в большом количестве пыльцы и спор, что впоследствии приводит к высоким показателям общей концентрации пыльцы и спор в верхнем слое донных отложений водоема. Минимальную концентрацию пыльцевых зерен в отложениях Южного Онего можно объяснить песчанистым типом отложений в данной акватории озера, из которых пыльца и споры легко вымываются. Несмотря на различия в показаниях концентрации пыльцы и спор в образцах поверхностных донных отложений в разных акваториях озера, палиноспектры их имеют существенное сходство, что указывает на достаточно равномерное таксономическое распределение палинологического материала по всей площади водоема.

Неоднозначна картина с концентрацией пыльцы и спор в образцах ловушек. Так, в ловушке (№1) из Кондопожской губы концентрация пыльцы и спор оказалась значительно ниже, чем в образцах верхнего слоя донных отложений этого же участка. В ловушках (№4) из Южного Онего и Петрозаводской губы (№25) концентрация выше, чем в образцах верхнего слоя донных отложений данных участков. В Большом Онего, как в поверхностных донных отложениях, так и в ловушке (№13), выявлены примерно одинаковые значения концентрации пыльцы. Также стоит отметить повышенное содержание пыльцы Betula spp. в образцах ловушек по сравнению с образцами поверхностных донных отложений. Однако, уже в первых сантиметрах донных отложений количество пыльцы Betula spp. снижается. Минимальные содержания и концентрация пыльцы Betula spp. наблюдаются в образцах Южного Онего и в некоторых образцах Большого Онего. Но в общих чертах (преобладание в спектрах пыльцы древесных пород с доминированием среди них пыльцы P. sylvestris, Betula spp., присутствие спор в незначительном количестве) по составу представленных пыльцы и спор спектры ловушек не обнаруживают значительных отличий от спектров поверхностных донных отложений озера.

По данным предыдущих исследований, в заливах, испытывающих наибольшее антропогенное воздействие, таких как Петрозаводская и Кондопожская губы, в составе фитопланктона отмечалось максимальное число видов-индикаторов повышенной трофности, таких как содержание Diatoma tenuis, Fragilaria crotonensis и Stephanodiscus hantzschii. [Чекрыжева 2012, 2015]. Однако, в пробах из СЛ эти виды немногочисленны, и 
их доля в составе диатомовых комплексов, как правило, не превышает 1\%. Отчасти это может объясняться плохой сохранностью тонких створок этих видов, растворяющихся уже в процессе погружения на дно после отмирания клетки. Тем не менее, их крайне низкая численность в составе диатомовых комплексов из СЛ должна в определенной мере отражать их сравнительно невысокий вклад в состав живых водорослевых сообществ, по крайне мере в течение периода экспозиции. Таким образом, можно предположить снижение антропогенного воздействия на экосистему Онежского озера в последние несколько лет.

Доля бентосных диатомей составляет 8-39\%, тем самым указывая на их второстепенную роль в составе диатомовых комплексов из СЛ. Преобладают обрастатели (8-33\%), среди которых наибольшее распространение имеет Tabellaria fenestrata, многочисленная (6-13\%) на всех станциях, за исключением Кондопожской губы, где ее численность не превышает 3\%. T. fenestrata - наиболее характерный вид в сообществах диатомей-обрастателей Онежского озера. Она также многочисленна в составе летнего и осеннего фитопланктона в результате разноса ее лентовидных колоний по акватории озера из мелководных районов, где она обитает в сообществах макрофитов [Растительный..., 1968]. Наиболее высокое содержание обрастателей (>20\%) отмечено в пробах из СЛ из Лижемской и Уницкой губ, заливов Малое Онего, Заонежского и Повенецкого, для которых характерны наибольшие площади зарастания макрофитами [Онежское... 2010]. Наиболее высокая численность как обрастателей, так и донных диатомей (33\% и 6\%, соответственно) отмечена на самой глубоководной станции - в Повенецком заливе (96 м). Очевидно, значительные площади мелководий, высокая прозрачность воды и особенности гидродинамического режима этого удаленного от основной акватории залива, способствуют существованию здесь большого разнообразия субстрата, доступного для колонизации бентосными диатомеями. В результате разноса подводными течениями, створки обрастателей и донных диатомей аккумулируются на дне глубоководной впадины в северной части залива, которая играет роль естественной седиментационной ловушки.

На примере исследования морей академиком А.П. Лисицыным с коллегами показано, что минеральный состав взвеси определяется поставкой материала не только из водосборного бассейна реками, но также из взаимодействующих геосфер (атмосфера, криосфера, биосфера) [Лисицын, 2010]. В Онежском озере, согласно нашим данным, минеральная часть осадочного материала СЛ соответствует минеральному составу терригенного материала, поступающего в озеро с речным стоком, эоловым разносом и абразией берегов. Наиболее активная абразия берегов свойственна для территории Южного Онего, что и отражается присутствием максимального количества зерен кварца, 
мусковита и минимального количества пыльцы, спор и другого органического детрита. Для фиордово-шхерного побережья заливов, где берега обладают наибольшей устойчивостью и не подвержены существенным изменениям, основная часть материала поступает с речным стоком.

Наибольшие колебания в геохимическом составе обнаружены по всем изученным элементам во взвеси на фильтрах, особенно по $\mathrm{Mn}, \mathrm{Cu}, \mathrm{Ca}$; по $\mathrm{Hg}$ во взвешенном материале из СЛ и по Mn, Мо в донных отложениях. При этом выявлено полное унаследование величин содержаний элементного состава материала СЛ и донного осадка в разных районах озера, за исключением высоких концентраций ртути во взвеси СЛ и иногда молибдена в донных отложениях. При отсутствии минеральных фаз ртути, молибдена, можно предположить их сорбцию органическим матриксом или гидроокислами/окислами марганца и железа. Обычно адсорбция Мо характерна на аморфных гидроксидах Mn. Распределение Мо, которое имеет сходство с фазами железа и марганца в донных отложениях Онежского озера авторами описано ранее в ряде публикаций [Strakhovenko et al, 2020а, б]. Так как максимальные концентрации ртути и марганца выявлены именно в губах северо-западной части озера, то основным источником их поступления являются речные или снеготалые воды. При осаждении взвеси на дно, её значительная часть подвергается воздействию микроорганизмов, процессам биотурбации, взмучиванию, переотложению и, возможно, что большая часть ртути возвращается назад в водную толщу озера. В случае современного источника ртути эти процессы ещё не находят своего отражения в донных осадках. Данный вопрос требует дальнейшего изучения.

\section{ЗАКЛЮЧЕНИЕ}

Впервые проведено исследование минерального состава взвешенного вещества водной толщи Онежского озера в сопоставлении с поверхностным слоем донных осадков. Выявлено, что минеральная часть рассеянного осадочного вещества, поступившая в озеро, достигает донный осадок без существенных изменений. Осадочный материал СЛ во всех районах Онежского озера, также, как и донный осадок, обогащен кварцем, полевыми шпатами (альбитом, олигоклазом, калиевым полевым шпатом), слюдами (мусковитом, биотитом), гидроокислами железа, иллитом и хлоритом. Среди крупных обломков минералов и их сростков присутствуют амфибол (роговая обманка, тремолит), пироксен (диопсид), эпидот, апатит, доломит и акцессорные минералы - магнетит, ильменит, циркон, рутил, монацит и др. Обычно эти минералы составляют небольшую часть от общей массы минералов (до 15\%), но их количество сильно варьирует по акватории озера 
и зависит от состава горных пород прилегающих водосборных территорий. В составе иллита и хлорита донных отложений резко преобладает железо в отличие от их состава во взвеси на фильтрах и в материале СЛ. Деградированные минералы слюд, привнесенными реками, регенерируются до нормальных железистых иллитов и хлоритов непосредственно в самой верхней части донного осадка.

Установлено, что геохимия вещества седиментационных ловушек во многом сходна с геохимией верхней части донных осадков (0-10 см) в различных районах Онежского озера, за исключением содержаний марганца и ртути. Выявлены высокие концентрации Hg в осадочном материале из СЛ. И наоборот более высокие значения содержаний Mn, Mo в донных отложениях. Марганцевые минеральные фазы, на которых адсорбируется молибден, формируются в водной толще Онежского озера и образуются в верхней окисленной части разреза донных отложений.

Результаты проведенных палинологических исследований взвеси из СЛ и поверхностных донных отложений Онежского озера позволили установить, что состав и соотношение основных компонентов поверхностных спорово-пыльцевых спектров дают адекватное представление о растительных сообществах на побережье озера и его бассейна. Региональная составляющая (деревья представлены P. sylvestris, Betula spp., Picea, Alnus, Populus, травы Cyperaceae, Poaceae, Amaranthaceae, Asteraceae, споровые растения Sphagnum, Polypodiophyta) палинокомплекса остается относительно стабильной на всех исследованных участках по акватории озера. Имеющиеся различия обусловлены локальными особенностями каждого обследованного участка. Таксоны, как макрофиты, так и прибрежная растительность, обильно произрастающие рядом с изученными точками отбора образцов, вносят существенный вклад в облик СПС. Исходя из полученного распределения пыльцы и спор в верхних горизонтах донного осадка, материала СЛ можно предположить, что регулируют транспортировку пыльцы и спор в озеро и их последующее перераспределение по акватории и захоронение в осадках три основные составляющие: речной сток, ветровой разнос, береговая абразия.

Результаты изучения диатомовых комплексов из СЛ Онежского озера показали, что наиболее многочисленные виды диатомей их составе являются характерными представителями современных сообществ диатомового планктона. Особенности состава диатомовых комплексов из СЛ объясняются локальными особенностями исследованных участков Онежского озера, такими как степень антропогенного воздействия, распространение макрофитов, рельеф дна и т.п.; виды- индикаторы антропогенного эвтрофирования в СЛ немногочисленны, что отчасти является результатом плохой 
сохранности их створок, а также указывает на их незначительный вклад в состав живых водорослевых сообществ, по крайней мере, в течение периода экспозиции.

Исследование выполнено при финансовой поддержке РФФИ в рамках научного проекта № 19-05-50014 (изучение минерального, геохимического состава, диатомового и микропалеонтологического состава взвеси, осадочного материала и донных отложений) и Госзадания ИВПС КарНЦ РАН (НИС Эколог, установка СЛ и анализ воды).

\section{СПИСОК ЛИТЕРАТУРЫ}

1. Арестова Н. А., В. П. Чекулаев, С. Б. Лобач-Жученко, Г. А. Кучеровский Формирование архейской коры древнего Водлозерского домена, Балтийский щит стратиграфия// Геологическая корреляция, 2015, том 23 (2), с. 3-16.

2. Белкина Н. А. Фосфор в донных отложениях Онежского озера // Известия Российского государственного педагогического университета имени А. И. Герцена, СПб., 2015, N 173, с. 97-109.

3. Белкина Н.А. Загрязнение нефтепродуктами донных отложений Петрозаводской губы Онежского озера // Водные ресурсы, 2006, т. 33 (2), с.181-187.

4. Белкина Н.А. Изменение окислительно-восстановительного состояния озерных донных отложений под влиянием антропогенных факторов (на примере Ладожского и Онежского озер) // Общество. Среда. Развитие, 2014, № 3, с.152-158.

5. Белкина Н.А. Ретроспективная оценка донных отложений Кондопожской губы Онежского озера // Водные ресурсы, 2005, т. 32 (6), с. 689-699.

6. Белкина Н.А., Субетто Д.А., Ефременко Н.А., Кулик Н.В. Особенности распределения микроэлементов в поверхностном слое донных отложений Онежского озера // Наука и образование, 2016, № 3 (83), с. 135-139.

7. Бискэ Г.С., Лак Г.Ц., Лукашов А.Д. и др. Строение и история котловины Онежского озера. Петрозаводск, Труды института геологии КарНЦ РАН, Труды института геологии КарНЦ PAH, 1971, 74 с.

8. Васильева Е.П. Донные отложения. Экосистема Онежского озера и тенденции ее изменения. Л., 1990, с. 147-175.

9. Онежское озеро. Экологические проблемы/ Под ред. Н. Н. Филатова. Петрозаводск, Карельский НЦ РАН, 1999, 293 с.

10. Государственная геологическая карта РФ масштаба 1:200000. Издание второе. Серия Карельская. Лист Р-36-XII (Медвежьегорск). Объяснительная записка. СПб., ВСЕГЕИ, 2013, 304 c.

11. Давыдова Н. Н. Диатомовые водоросли - индикаторы природных условий водоемов в голоцене. Л., Наука, 1985, 244 с.

12. Калинкина Н. М., Белкина Н. А., Сидорова А. И., Галибина Н. А., Никерова К. М. Биотестирование донных отложений Онежского озера с учетом их химического состава и показателей состояния глубоководного макрозообентоса // Принципы экологии, 2017, (1), с. 81-103.

13. Кулик Н.В., Белкина Н.А., Ефременко Н.А. Поступление, трансформация и распределение марганца в Онежском озере // Московский экономический журнал, 2020, (1), с. 13-17.

14. Куликова Т.П., Сярки М.Т. Влияние антропогенно го евтрофирования на распределение зоопланкто на в Кондопожской губе Онежского озера // Водные ресурсы, 2004, Т. 31. (1), с. 91-97.

15. Куприянова Л.А., Алешина Л.А. Пыльца и споры растений флоры СССР. Л., Наука, $1972 .$, T.1, 171 c. 
16. Куприянова Л.А., Алешина Л.А. Пыльца и споры растений флоры СССР. Л., Наука, Т. 2, 1978, 183 с.

17. Лаврова Н.Б. Палинологическая характеристика донных отложения Онежского озера // Геология и полезные ископаемые Карелии, Петрозаводск, КарНЦ РАН, 2004, Вып.7, с. 219-225.

18. Лисицын А. П. академик, А. Н. Новигатский, В. П. Шевченко, А. А. Клювиткин, М. Д. Кравчишина, А. С. Филиппов, Н. В. Политова Рассеянные формы осадочного вещества и их потоки в океанах и морях на примере Белого моря (результаты 12 лет исследований) // ДОКЛАДЫ АКАДЕМИИ НАУК, 2014, т. 456 (3), с. 355-359.

19. Лисицын А.П. Новый тип седиментогенеза в Арктике - ледовый морской, новые подходы к исследованию процессов // Геология и геофизика, 2010, Т. 51 (1), с. 18-60.

20. Лисицын А.П. Процессы океанской седиментации. М., Наука, 1978, 392 с.

21. Лозовик П. А. Гидрогеохимические критерии состояния поверхностных вод гумидной зоны и их устойчивость к антропогенному воздействию: Автореф. дис. ... д-ра хим. наук . M., 2006, 58 с.

22. Лозовик П.А., Н.А.Ефременко Аналитические, кинетические и расчетные методы в гидрохимической практике. СПб., Нестор-История, 2017, 272 с.

23. Онежская палеопротерозойская структура (геология, тектоника, глубинное строение и минерагения). Петрозаводск, КНЦ РАН, 2011, 431 с.

24. Онежское озеро. Атлас / Отв. ред. Н. Н. Филатов. Петрозаводск, КарНЦ РАН, 2010, 151 с.

25. Лозовик П. А., Н. В. Кулик, Н. А. Ефременко Литофильные элементы и тяжелые металлы в Онежском озере: источники поступления, содержание и трансформация // Труды Карельского научного центра РАН, 2020, № 4, с. 62-74.

26. Растительные ресурсы Ладожского озера. Ленинград, изд-во Ленингр. ун-та, 1968, 231 с.

27. Ранний докембрий Балтийского щита. Ред. Глебовицкий В.А. СПб., Наука, 2005, 711 с.

28. Ромашкин А.Е., Рычанчик Д.В., Голубев А.И. Геохимия РЗЭ углеродсодержащих пород Онежской структуры // Геология и полезные ископаемые Карелии. Петрозаводск, КарНЦ РАН, 2014, Вып. 17, с. 74-85.

29. Ронов А.Б., Мигдисов А.А. Количественные закономерности строения и состава осадочных толщ Восточно Европейской платформы и Русской плиты и их место в ряду древних платформ мира // Литология и полез. Ископаемые, 1996, № 5, с. 451-475.

30. Россолимо Л.Л. Основы типизации озер и лимнологического районирования. Накопление вещества в озерах. М., Наука, 1964, 96 с.

31. Семенович Н.И. Донные отложения Онежского озера. Л., Наука, 1973, 104 с.

32. Система Белого моря. Том III. Рассеянный осадочный материал гидросферы, микробные процессы и загрязнения. - М.: Научный мир, 2013. - 668 с

33. Страхов Н.С. Основы теории литогенеза. М., Изд-во АН СССР, 1962, Т. 3, 550 с.

34. Субетто Д.А. Донные отложения озер: палеолимнологические реконструкции. СПб., Издво: РГПУ им. А.И.Герцена, 2009, 343 с.

35. Тейлор С.Р., МакЛеннан С.М. Континентальная кора: её состав и эволюция. М., Мир, 1988, 384 с.

36. Федорец Н.Г. Геохимические особенности песчаных иллювиально-гумусово-железистых подзолов // Эколого-геохимические и биологические закономерности почвообразования в таежных лесных экосистемах. Петрозаводск, КарНЦ РАН, 2009, 176 с.

37. Филимонова Л.В., Лаврова Н.Б. Изучение палеогеографии Онежского озера и его бассейна с использованием комплекса методов. Петрозаводск, Труды Карельского научного центра PAH, 2017, №10, с. 86-100.

38. Холодов В.Н., Недумов Р.И., Голубовская Е.В. Фациальные типы осадочных железорудных месторождений и их геохимические особенности Сообщение 1. Фациальные группы осадочных руд, их литология и генезис // Литология и полез. ископаемые. 2012, № 6, с. 503-531.

39. Хотинский Н.А. Голоцен Северной Евразии. Москва, Наука, 1977, 200 с. 
40. Чекрыжева Т.А. Диатомовые водоросли в планктоне Онежского озера // Тр. КарНЦ РАН, 2012, №4, с. 110-116.

41. Чекрыжева Т.A. Таксономическая и экологическая характеристика фитопланктона Онежского озера // Тр. КарНЦ РАН, 2012, №1, с. 56-69.

42. Чекрыжева Т.А. Таксономическая и экологическая характеристика фитопланктона Онежского озера // Тр. КарНЦ РАН, 2012, №1, с. 56-69.

43. Чижикова Н.П., Копцик Г.Н., Мурашкина-Миис М.А. Минералогический состав тонкодисперсной фракции почв конечной зоны Валдайского оледенения // Почвоведение. 2000, № 8, с. 976-988.

44. Шевченко В.П. Влияние аэрозолей на среду и морское осадконакопление в Арктике. М., Наука, 2006, 226 с.

45. Buck E.C., Bates J.K. Microanalysis of colloids and suspended particles from nuclear wastes glass alteration // Appl. Geochem. 1999, Vol. 14 (5), p. 635-653.

46. Faegri K., Iversen J. Textbook of Pollen Analysis. The Blackburn Press, 1989, 328 p.

47. Grimm E. Tilia software 2.0.2. Illinois State Museum Research and Collection Center, Springfield, 2004, 201pp.

48. Krammer K., Lange-Bertalot H. Bacillariophyceae // Süßwasserflora von Mitteleuropa. Stuttgart: Gustav Fisher Verlag, 1986. Bd 2. Teil 1. 876 S. 1988. Bd 2. Teil 2. 596S. 1991. Bd 2. Teil 3. 576 S. 1991. Bd 2. Teil 4. 437 S.

49. McCarthy J.F., Degueldre C. Sampling and characterization of colloids and particles in groundwater for studying their role in the subsurface transport of contaminants // Environ. Particles. J. Buffle, H. Van Leeuwen - eds., Lewis Publishers (Chelsea, MI), 1992, p. 247-315.

50. Reille M. Pollen et spores d'Europe et d'Afrique du nord Supplement 1. Laboratoire de botanique historique et palynologie, URA CNRS, Marseille, France, 1995, 520 p.

51. Reille M. Pollen et spores d'Europe et d'Afrique du nord Supplement 2. Laboratoire de botanique historique et palynology. URA CNRS, Marseille, France, 1998, $530 \mathrm{p}$.

52. Reille M. Pollen et spores d'Europe et d'Afrique du nord. Laboratoire de botanique historique et palynologie. URA CNRS, Marseille, France, 1992, 520 p.

53. Saarnisto M., Saarinen T. Deglaciation chronology of the Scandinavian Ice Sheet from the lake Onega basin to the Salpausselkya End Moraine // Global and Planetary Changes, 31. 2001, (31), p. 333-405.

54. Stokmarr J. Detervinatio of spore concentration with in electronic particlecounter. Geological; Survey of Denmark. Kobenhavn, 1972. P. 87-89.

55. Strakhovenko V.D., Subetto D., Ovdina E.A., Belkina N., Efremenko N. Distribution of elements in iron, manganese formations in bottom sediments of Lake Onego (NW Russia) and small lakes (Shotoz ero and Surgubskoe) of adjacent territories // Minerals, 2020a, 10, p. 440-450.

56. Strakhovenko V.D., Subetto D., Ovdina E.A., Danilenko I.V., Belkina N., Efremenko N., Maslov A. Mineralogical and geochemical composition of Late Holocene bottom sediments of Lake Onego // Journal of Great Lakes Research, 2020б, (46), p. 443-455. 


\section{ПОДРИСУНОЧНЫЕ ПОДПИСИ К СТАТЬЕ «ПЕРВЫЕ ДАННЫЕ ПО МИНЕРАЛОГИИ И ГЕОХИМИИ ВЗВЕСИ ОНЕЖСКОГО ОЗЕРА».}

\section{В.Д. Страховенко ${ }^{1,2}$, Н.А. Белкина ${ }^{3}$, Н.А. Ефременко ${ }^{3}$, М.С. Потахин ${ }^{3}$, Д.А. Субетто ${ }^{4}$, Л.А. Фролова ${ }^{5}$, Г.Р. Нигаматзянова ${ }^{5}$, А.В. Лудикова ${ }^{6}$, Е.А. Овдина ${ }^{1}$ \\ Рисунок 1 - Фото седиментационной ловушки УСЛ-100 с осадком (Кондопожская губа, Онежское озеро, сентябрь 2019 г.)}

Рисунок 2. Карта-схема Онежского озера с его водосборным бассейном с точками пробоотбора взвеси, вещества из седиментационных ловушек и донных отложений.

Рисунок 3. Микрофотографии, выполненные с использованием СЭМ образцов онежской взвеси на фильтрах, отобранных в Повенецкой заливе (а), Малом Онего (б) и Кондопожской губе (в), панцирей и биодетрита диатомовых водорослей, пыльцы, спор, отдельных зерен минералов и их агрегаты (пеллетные комки): (А) 1 - пыльца, 2 - альбит, 3 - мусковит, 4 - иллит (Mg, Fe), 5 - скелеты и обломки панцирей диатомовых; (Б) 1чешуйчатый агрегат мусковита; (В) 1 - альбит, 2 - панцири и биодетрит диатомовых водорослей, 3 -окислы марганца.

Рисунок 4. Микрофотографии, выполненные с использованием СЭМ, минерального состава взвешенного материала СЛ Онежского озера, отобранного в Петрозаводской губе (а) и Кондопожской губе (б). Отдельные зерна, кристаллы минералов и их агрегаты: (А) 1 - кварц, 2 - альбит, 3 - мусковит, 4 - хлорит (Mg>Fe), 5 - иллит (Mg, Fe), 6 - окислы $\mathrm{Mn}, 7$ - скелеты и обломки панцирей диатомовых; (Б) 1 - альбит, 2 - иллит (Fe, Mg), 3 - иллит (Fe $>\mathrm{Mg}$ ) шаровидной морфологии, 4 -шаровидный пористый (техногенный флюс ?) калиевый полевой шпат, 5 -хлорит $(\mathrm{Mg}>\mathrm{Fe}), 6$ - мусковит, 7 - диопсид, 8 - скелеты и обломки панцирей диатомовых.

Рисунок 5. Микрофотографии, выполненные с использованием СЭМ агрегатов шаровидной морфологии из взвешенного материала СЛ Онежского озера, отобранного в Кондопожской губе: (А) 1 - агрегат шаровидной морфологии полый внутри с пористой текстурой и имеющих состав калиевого полевого шпата, 2 - отдельные зерна хлорит (Mg>Fe), 3 - фрамбоэдр пирита; (Б) 1 -хлорит (Fe); (B) 1 - кварц, в котором скелетные кристаллы хлорит (Fe).

Рисунок 6. Микрофотографии, выполненные с использованием СЭМ взвеси на фильтре (А) и взвешенного материала СЛ (Б), отобранного в Малом Онего: (А) 1 - скелеты и обломки панцирей диатомовых; 2 - отдельные зерна альбита; 3 - отдельные зерна хлорит (Mg, Fe); (Б) 1 - отдельные зерна альбита;; 2 - мелкие ватоподобные чешуйчатые агрегаты иллита (Mg, Fe); 3 - отдельные кристаллы мусковита; 4 - отдельные зерна хлорита (Mg, $\mathrm{Fe}) ; 5$ - скелеты и обломки панцирей диатомовых.

Рисунок 7. Распределение содержаний макроэлементов в взвеси на фильтрах, осадочного материала СЛ, донного осадка Онежского озера из разных скважин, нормированные к содержанию в PAAS.

Рисунок 8. Распределение содержаний микроэлементов в взвешенном материале СЛ и донного осадка Онежского озера из разных скважин, нормированные к содержанию в PAAS в сопоставлении с распределением их содержаний в горных породах водосборной площади озера. 
Рисунок 9. Спорово-пыльцевые спектры поверхностных донных отложений и седиментационных ловушек озера Онежское. 
Основные физико-химические характеристики осадочного материала из СЛ.

\begin{tabular}{|c|c|c|c|c|c|c|c|c|}
\hline Район Онежского озера & $\mathrm{H}$ & $\mathrm{pH}$ & Eh & $\mathrm{m}$ & Порист. & $\mathrm{d}$ & $\mathrm{N}\left(\mathrm{NH}_{4}\right)$ & $\mathrm{P}_{\text {мин }}$ \\
\hline & M & & $\mathrm{MB}$ & $\Gamma$ & & $\Gamma / \mathrm{CM}^{3}$ & $\%$ & $\%$ \\
\hline Повенецкий залив (W2) & 96 & 7,14 & 212 & $\begin{array}{l}0,099 \\
0\end{array}$ & 0,99 & $\begin{array}{l}1,086 \\
8\end{array}$ & 0,006 & 0,101 \\
\hline Заонежский (N1) & 20 & 7,32 & 302 & $\begin{array}{l}0,099 \\
2\end{array}$ & 0,99 & $\begin{array}{l}1,091 \\
3\end{array}$ & 0,005 & 0,120 \\
\hline Малое Онего (L11) & 40 & 7,24 & 283 & $\begin{array}{l}0,135 \\
9\end{array}$ & 0,96 & $\begin{array}{l}1,086 \\
4\end{array}$ & 0,006 & 0,121 \\
\hline Лижемская губа (GL3) & 56 & 7,14 & 229 & $\begin{array}{l}0,067 \\
6\end{array}$ & 0,99 & $\begin{array}{l}1,051 \\
7\end{array}$ & 0,009 & 0,134 \\
\hline Уницкая губа (GU4) & 30 & 6,85 & 263 & $\begin{array}{l}0,068 \\
7\end{array}$ & 0,99 & $\begin{array}{l}1,071 \\
9\end{array}$ & 0,010 & 0,129 \\
\hline Кондопожская губа (K6) & 80 & 6,90 & 312 & $\begin{array}{l}0,067 \\
7\end{array}$ & 0,99 & $\begin{array}{l}1,049 \\
8\end{array}$ & 0,012 & 0,232 \\
\hline Петрозаводская губа (Р3) & 28 & 7,23 & 248 & $\begin{array}{l}0,054 \\
4\end{array}$ & 0,96 & $\begin{array}{l}1,014 \\
1\end{array}$ & 0,009 & 0,155 \\
\hline Большое Онего(В1) & 86 & 6,55 & 362 & $\begin{array}{l}0,077 \\
5 \\
\end{array}$ & 0,99 & $\begin{array}{l}1,073 \\
7 \\
\end{array}$ & 0,007 & 0,145 \\
\hline Южное Онего (S3) & 28 & 6,34 & 376 & $\begin{array}{l}0,109 \\
5\end{array}$ & 0,99 & $\begin{array}{l}1,093 \\
6\end{array}$ & 0,006 & 0,080 \\
\hline
\end{tabular}


Скорость осадконакопления в Онежском Озере по данным из СЛ, I - неконсолидированная взвесь; II - уплотненный осадок на глубине 5 см; III - уплотненный осадок на глубине 20 см и донный осадок путем оценки активности ${ }^{137} \mathrm{Cs}$ и ${ }^{210} \mathrm{~Pb}$ (мм/год)

\begin{tabular}{|c|c|c|c|c|c|}
\hline Район & I & II & III & \multicolumn{2}{|c|}{${ }^{137} \mathrm{Cs} \mathrm{и}{ }^{210} \mathrm{~Pb}$} \\
\hline \\
\hline \multicolumn{2}{|l|}{ Материал СЛ } & $\begin{array}{c}\text { Донный осадок } \\
(0-2 \mathrm{~cm})\end{array}$ & $\begin{array}{l}\text { Донный осадок } \\
(2-25 \text { см })\end{array}$ \\
\hline Южное Онего & 11,7 & 0,47 & 0,2 & 1,5 & 0,43 \\
\hline Малое Онего & 1,6 & 0,16 & 0,11 & 1,0 & 0,23 \\
\hline
\end{tabular}




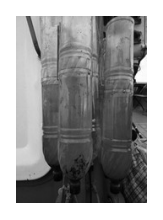




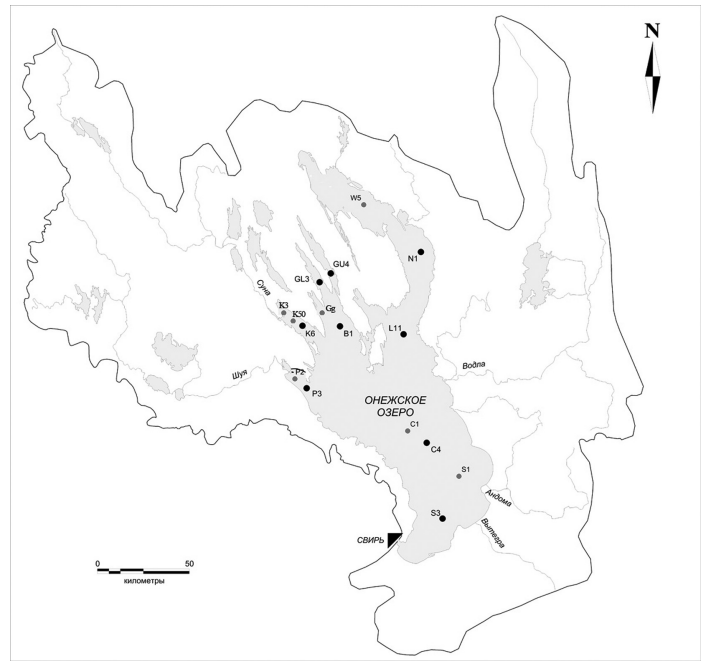




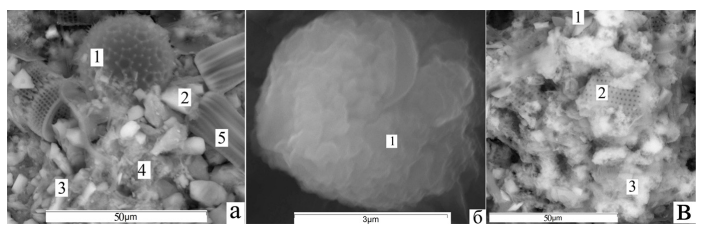




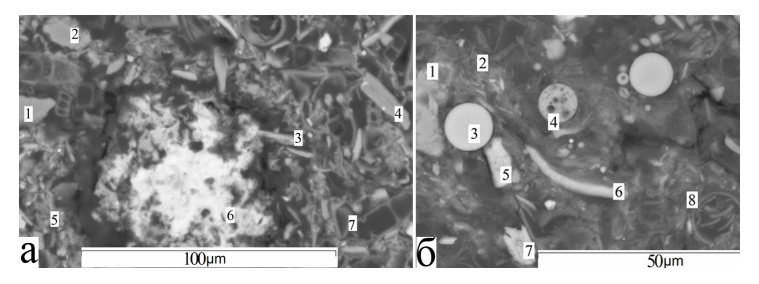




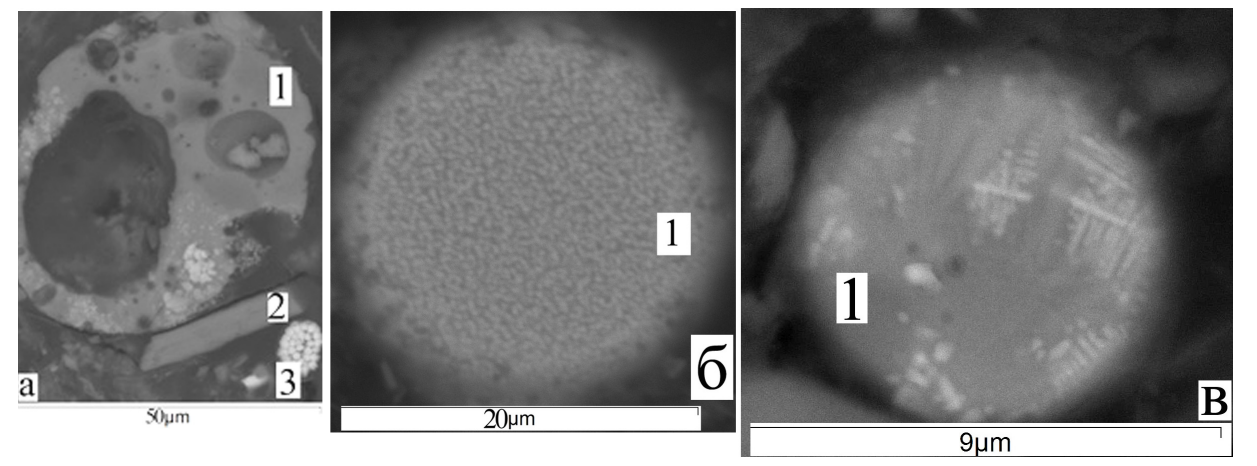




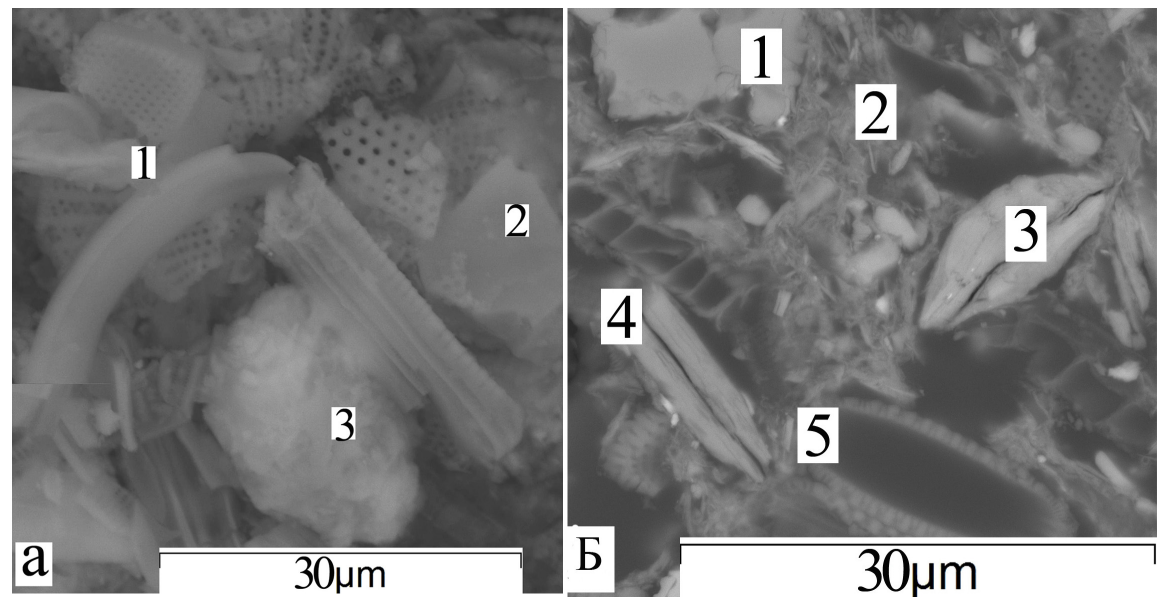




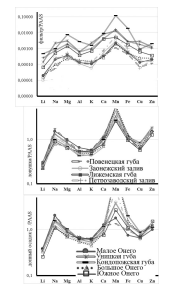


IMUANAN

DANANA

FWNA $=$ WA

$\overline{N A}=$

$\bar{N}=$ 


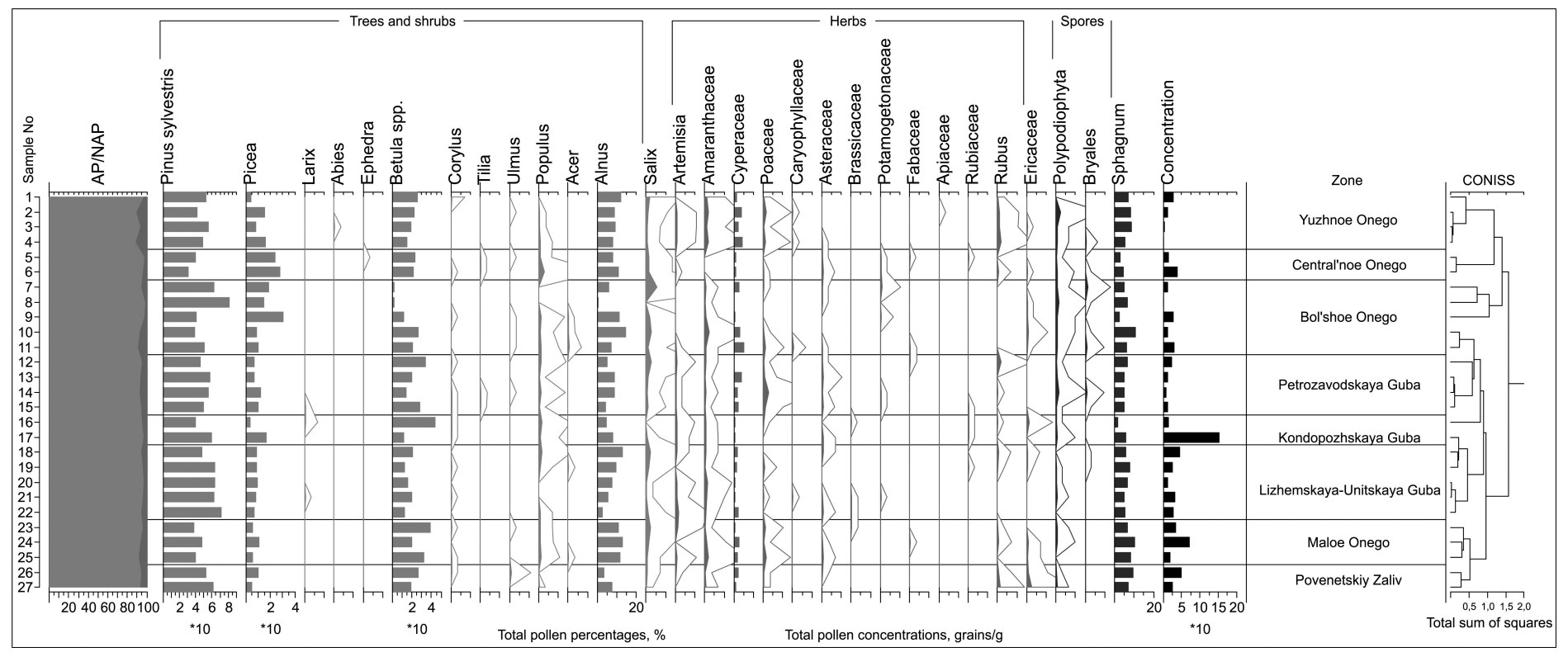

